\title{
Sulphate reduction associated with roots and rhizomes of the marine macrophyte Zostera marina
}

\author{
Vibeke Blaabjerg, Kai Finster* \\ Department of Microbial Ecology, Institute of Biological Sciences, Bldg 540, University of Aarhus, DK-8000 Aarhus C, Denmark
}

\begin{abstract}
The activity, the location and the oxygen sensitivity of sulphate reducers associated with sediment-free roots and rhizomes of the seagrass Zostera marina were investigated. Sulphate reduction rates were determined after treatment of roots and rhizomes with hypochlorite or exposure to air. Untreated roots and rhizomes served as controls. In general, root- as well as rhizome-associated sulphate reduction rates were high $\left(20\right.$ to $\left.50 \mu \mathrm{mol} \mathrm{SO}{ }_{4}^{2-} \mathrm{gdw}^{-1} \mathrm{~d}^{-1}\right)$. After surface sterilisation, the sulphate reduction rates decreased by about $90 \%$, indicating that most of the sulphate reducers were associated with the surface of the roots and rhizomes. Pre-incubation of roots for $8 \mathrm{~h}$ in the nresence of 0 to $20 \%$ oxvgen (in steps of $2 \%$ ) did not affect the sulphate reduction rates determined posterior under anoxic conditions. This demonstrates a high tolerance of root surface-associated sulphate reducers towards oxygen.
\end{abstract}

KEY WORDS: Sulphate reducing bacteria - Roots - Rhizomes Seagrass beds . Oxygen tolerance

The rhizosphere of marine macrophytes has been intensively investigated in recent years. The studies include rate measurements of e.g. bacterial productivity, nitrogen fixation, and sulphate reduction, as well as the identification of microorganisms by application of molecular tools (e.g. Smith \& Hayasaka 1982, Moriarty et al. 1985, Glazebrook et al. 1996, Isaksen \& Finster 1996, Rooney-Varga et al. 1997, Welsh et al. 1997). In general, the authors focus on interactions between the macrophyte and the associated microorganisms. Recently, Blaabjerg et al. (1998) demonstrated that sulphate reduction rates in a Zostera marina bed varied throughout a diel cycle, with significantly higher rates in the light than in the dark. The authors also showed that sulphate reduction responded rapidly when shifting from light to dark and vice versa. This indicates a

\footnotetext{
-Addressee for correspondence.

E-mail: kai.finster@biology.aau.dk
}

close physical coupling between the roots/rhizomes and the sulphate reducers.

These observations stimulated the studies on which we report here. We were interested in: (1) determining if sulphate reducers were present on roots and rhizomes and quantifying sulphate reducing activity, (2) roughly localising the sulphate reducers on the roots and rhizomes and (3) determining the tolerance of sulphate reducers towards oxygen. The results given below represent, to our knowledge, the first study of sulphate reduction on isolated subterranean plant compartments.

Material and methods. Study site and sampling procedure: The sampling site was located in Logstør Bredning, Limfjorden, Denmark (56 $58^{\prime} \mathrm{N}, 9^{\circ} 15^{\prime} \mathrm{E}$ ). Sediment with living plants was sampled in plexiglas tubes (10 cm i.d.) and transported to the laboratory in seawater-filled coolers. In the laboratory, the cores were stored in a seawater-filled aquarium at $12^{\circ} \mathrm{C}$ under shifting light/dark conditions (12 h:12 h). The storage time did not exceed $3 \mathrm{~d}$.

Sample preparation and experimental design: After leaf removal, the upper $6 \mathrm{~cm}$ of a sediment core was extruded from the plexiglas tube, cut off with a spatula and transferred to $\mathrm{N}_{2}$-flushed plastic bags. Roots and rhizomes were sorted out and transferred to a $\mathrm{N}_{2}$ flushed glass container. Roots were separated from the rhizomes with a forceps and stored in a separate container under nitrogen. All measurements of sulphate reduction rates were carried out in $10 \mathrm{ml}$ screw-cap sealed glass tubes. They were filled with $8 \mathrm{ml}$ of filtered, autoclaved, dithionite-reduced seawater leaving a headspace of $2 \mathrm{ml}$. Resazurin was added as a redox indicator. The screw caps of the glass tubes contained rubber septa which allowed the addition of ${ }^{35} \mathrm{~S}_{-} \mathrm{SO}_{4}{ }^{2-}$ with a syringe and a needle. Approximately, 0.2 to $0.6 \mathrm{~g}$ roots and 0.7 to $1.2 \mathrm{~g}$ rhizomes (wet weight) were used in each incubation. The experiments were initi- 
ated by the injection of $15 \mu \mathrm{l} 35$ to $75 \mathrm{MBq} \mathrm{ml}^{-1}$ ${ }^{35} \mathrm{~S}_{-} \mathrm{SO}_{4}{ }^{2-}$. The suspensions were vigorously mixed with a whirlymixer, incubated for 3 to $20 \mathrm{~h}$ at $22^{\circ} \mathrm{C}$ and stopped by injection of $2 \mathrm{ml}$ of a $2 \% \mathrm{Zn}$-acetate solution.

Sulphate reduction rates were determined as described by Isaksen \& Finster (1996). The dry weight of the incubated roots and rhizomes was determined after incubation at $105^{\circ} \mathrm{C}$ for $24 \mathrm{~h}$.

The distribution of sulphate reducers between the root/rhizome surface and the cortex was studied by sterilising the surface with hypochlorite. The procedure described by Smith \& Hayasaka (1986) was followed. Roots and rhizomes were incubated for 0.5 and $3.5 \mathrm{~min}$ in an oxygen-free $1.05 \%$ hypochlorite solution and washed afterwards 3 times in $\mathrm{N}_{2}$-flushed autoclaved seawater prior to incubation. Untreated roots and rhizomes served as controls.

The oxygen sensitivity of root-associated sulphate reducers was investigated by pre-incubating Zostera marina roots in screw-cap sealed glass bottles in the presence of 0 to $20 \%$ oxygen (in $2 \%$ intervals), respectively, for $8 \mathrm{~h}$. The oxygen concentration was measured throughout the incubation by gas chromatography and kept at a constant level.

The sulphate reduction rates were determined for each treatment.

Results and discussion. Our experiments clearly demonstrated that both roots and rhizomes of Zostera marina were colonised by sulphate reducers (Fig. 1a, b). Extrapolating from the sulphate reduction rates, the colonisation must have been substantial. Pooling all our experiments, root- and rhizome-associated sulphate reduction rates varied between 20 and $50 \mu \mathrm{mol}$ $\mathrm{gdw}^{-1} \mathrm{~d}^{-1}$. These rates were up to 20 times higher than rates determined with an equivalent amount of sediment (Blaabjerg et al. 1998). The rates were well correlated with the quantity of roots/rhizomes incubated (Fig. 1a, b). Assuming that the specific sulphate reduction rate of $10^{-14}$ to $10^{-15} \mathrm{~mol} \mathrm{SO}{ }_{4}^{2-} \mathrm{cell}^{-1} \mathrm{~d}^{-1}$ given in the literature (Ingvorsen \& Jørgensen 1984, Jørgensen \& Bak 1991) can be extrapolated to the root/rhizomeassociated sulphate reducers, the estimated number of cells from the above given rates was $10^{7}$ to $10^{9}$ cells $\mathrm{gdw}^{-1}$ or $10^{6}$ to $10^{8}$ cells $\mathrm{gww}^{-1}$ (wet weight). The number is 1 to 2 orders of magnitude higher than that which has been reported from unvegetated marine surface sediments (Jørgensen \& Bak 1991) but agreed very well with cell numbers found in surface sediment of a Zostera noltii-overgrown marine mudflat (Schaub \& van Gemerden 1996).

To determine the distribution of sulphate reducers between the surface and the cortex of the roots and rhizomes, a surface-sterilisation experiment was conducted. After surface sterilisation in a $1.05 \%$ hypochlo-
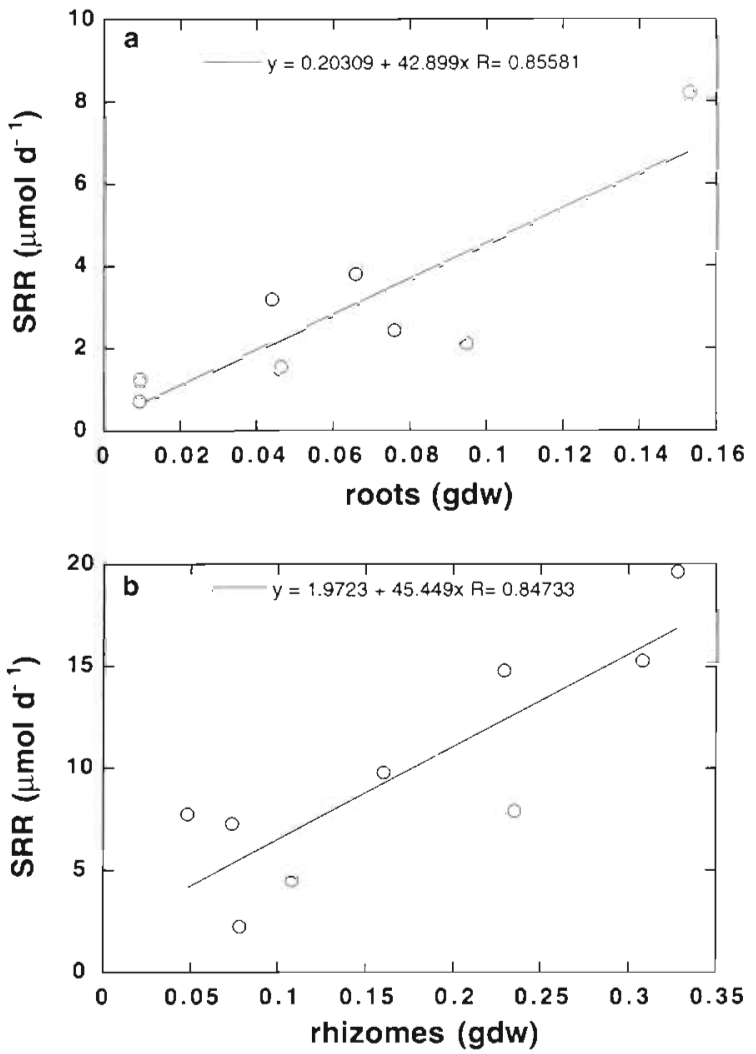

Fig. 1. Sulphate reduction rates ( $\mu$ mol d $\mathrm{d}^{-1}$ ) as a function of (a) roots and (b) rhizome dry weight ( $g \mathrm{dw}$ )

rite solution, the root-associated sulphate reduction rates decreased from about $40 \mu \mathrm{mol} \mathrm{gdw}^{-1} \mathrm{~d}^{-1}$ to about

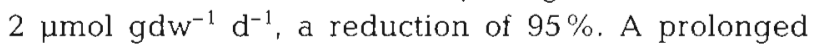
sterilisation period of $3.5 \mathrm{~min}$ reduced root-associated sulphate reduction rates by $98 \%$ (Fig. 2). Similarly, rhizome-associated sulphate reduction rates were reduced by $80 \%$ from about $21 \mu \mathrm{mol} \mathrm{gdw}^{-1} \mathrm{~d}^{-1}$ to $4.5 \mu \mathrm{mol} \mathrm{gdw}^{-1} \mathrm{~d}^{-1}$ after a sterilisation period of $0.5 \mathrm{~min}$. After $3.5 \mathrm{~min}$, rhizome-associated sulphate reduction rates decreased by $93 \%$ compared to a control (Fig. 2). Our results indicate that sulphate reducers were primarily associated with the surfaces of the roots and rhizomes and to a minor extent with the cortex. Similar observations were described by Smith \& Hayasaka (1982) when studying nitrogenase activity associated with Zostera marina roots. Surface sterilisation reduced $\mathrm{C}_{2} \mathrm{H}_{2}$ reduction by more than $99 \%$ indicating that by far the majority of the nitrogen fixers was associated with the root surface. We confirmed the presence of sulphate reducers in the cortex of roots and rhizomes by enriching sulphate reducers when surface-sterilised roots and rhizomes served as inocula and acetate, propionate, lactate, malate or ethanol served as energy/carbon sources. However, compared to enrichments with untreated root or rhizome inocula, 


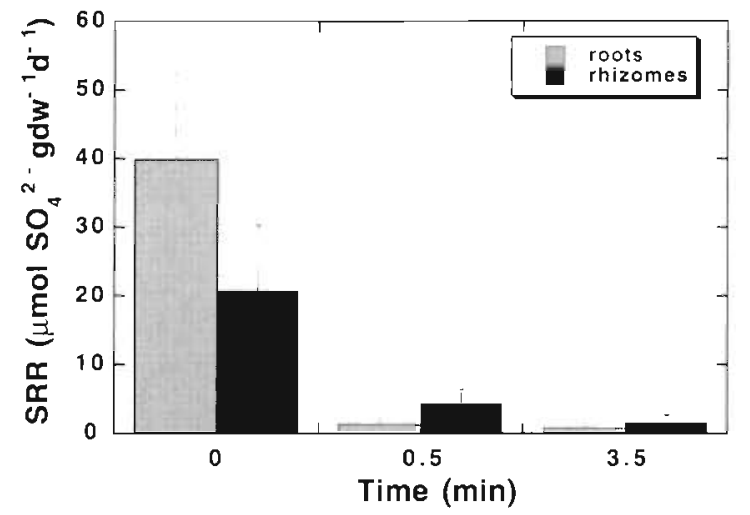

Fig. 2. Sulphate reduction rates (SRR) determined with surfacesterilised roots (grey) and rhizomes (black). Bars give standard errors of mean, $n=3$. Roots and rhizomes were surfacesterilised in a $1.05 \%$ hypochlorite solution for 0.5 and $3.5 \mathrm{~min}$, respectively. Untreated roots served as a control

bacterial growth and sulphide production were generally delayed when hypochlorite-treated roots or rhizomes were inoculated. With lactate, malate or ethanol as energy and carbon sources the delay was $1 \mathrm{wk}$. Propionate and acetate enrichments were delayed by 2 and 3 wk, respectively. Lactate, malate or ethanol enriched for Desulfovibrio-like sulphate reducers. From the lactate enrichment, a sulphate reducer related to the oxygen-tolerant species Desulfovibrio salexigens was isolated (Cypionka et al. 1985). The propionate and acetate enrichment cultures are not identified yet. A detailed characterisation of the cultures is under way.

Recent studies of e.g Sand-Jensen et al. (1982) showed that roots of Zostera marina leak oxygen into the environment. Accordingly, an experiment was initiated to examine the oxygen tolerance of sulphate reducers which thrive under these periodically oxic conditions. Interestingly, the root-associated sulphate reduction rates were not affected by $8 \mathrm{~h}$ pre-incubations in the presence of molecular oxygen in the range of 0 to $20 \%$ (Fig. 3). From the results obtained in our surface sterilisation experiment we concluded that most of the sulphate reducers were associated with the root surface. Consequently, they were not physically protected by the root tissue but directly exposed to oxygen. The oxygen tolerance of root-associated sulphate reducers is in good agreement with results obtained with pure cultures of sulphate reducers as well as with environmental samples (Hardy \& Hamilton 1981, Cypionka et al. 1985, Abdollahi \& Wimpenny 1990, Dannenberg et al. 1992, Johnson et al. 1997). The resistance to high oxygen concentrations may, however, not exclusively be a feature of the sulphate reducers per se, but a consequence of the close proximity to an oxygen-consuming matrix, the root tissue or

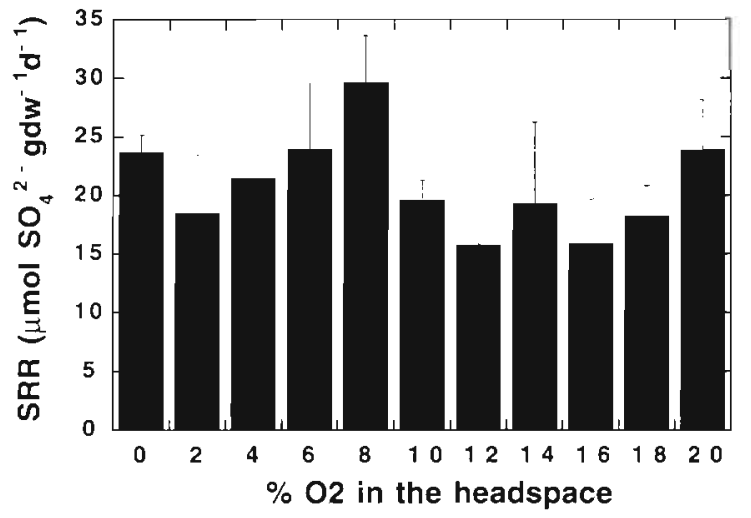

Fig. 3. Sulphate reduction rates measured with roots after an $8 \mathrm{~h}$ pre-incubation at constant oxygen concentrations ranging from 0 to $20 \%$ in the headspace. The oxygen concentrations were increased at $2 \%$ intervals. The bottles were incubated on a bottle roller to ensure homogenous distribution of oxygen. Bars give standard errors of mean, $n=3$

to other oxygen-consuming microorganisms which were also attached to the root surface.

Conclusion. In eelgrass-bearing marine sediments, sulphate reducers colonise both roots and rhizomes as demonstrated by high root-/rhizome-associated sulphate reduction rates. The large standard errors of the mean express the heterogeneity of the root/rhizome material and may be a consequence of different degrees of colonisation and/or variable food quality. The high oxygen tolerance of the root-associated sulphate reducers may either be an inherent capacity of the microorganisms or may result from interactions between aerobic eukaryotic and prokaryotic cells and the sulphate reducers.

Acknowledgements. The authors acknowledge the constructive criticism of an anonymous reviewer. This work is a contribution to the ELOISE Programme (ELOISE No. 053) in the framework of the ROBUST project carried out under contract ENV4-CT96-0218.

\section{LITERATURE CITED}

Abdollahi H, Wimpenny JWT (1990) Effects of oxygen on the growth of Desulfovibrio desulfuricans. J Gen Microbiol 136:1025-1030

Blaabjerg V, Mouritsen KN, Finster K (1998) Diel cycles of sulphate reduction rates in sediments of a Zostera marina bed (Denmark). Aquat Microb Ecol 15:97-102

Cypionka H, Widdel F, Pfennig N (1985) Survival of sulfatereducing bacteria after oxygen stress, and growth in sulfate-free oxygen-sulfide gradients. FEMS Microbiol Ecol 31:39-45

Dannenberg S, Korder M, Dilling W, Cypionka H (1992) Oxidation of $\mathrm{H}_{2}$, organic compounds and inorganic sulfur compounds coupled to reduction of $\mathrm{O}_{2}$ and nitrate by sulfate-reducing bacteria. Arch Microbiol 158:93-99

Glazebrook PW, Moriarty DJW, Hayward AC, MacRae IC 
(1996) Seasonal changes in numbers and the location of a particular bacterial strain Alteromonas sp. in seagrass sediments. Microb Ecol 31:1-13

Hardy JA, Hamilton WA (1981) The oxygen tolerance of sulfate-reducing bacteria isolated from North Sea waters. Curr Microbiol 6:259-262

Ingvorsen $\mathrm{K}$, Jørgensen BB (1984) Kinetics of sulfate uptake by freshwater and marine species of Desulfovibrio. Arch Microbiol 139:61-66

Isaksen M, Finster K (1996) Sulphate reduction in the root zone of the seagrass Zostera noltii on the intertidal flats of a coastal lagoon (Arcachon, France). Mar Ecol Prog Ser 137: $187-194$

Johnson MS, Zhulin IB, Gapuzan MER, Taylor BL (1997) Oxygen-dependent growth of the obligate anaerobe Desulfovibrio vulgaris Hildenborough. J Bacteriol 179 : $5598-5601$

Jørgensen BB, Bak F (1991) Pathways and microbiology of thiosulfate transformations and sulfate reduction in a marine sediment (Kattegat, Denmark). Appl Environ Microbiol 57:847-857

Moriarty DJW, Boon PI, Hansen JA, Hunt WG, Poiner IR, Pollard PC. Skyring GW, White DC (1985) Microbial biomass

Editorial responsibility: Tom Fenchel,

Helsingør, Denmark and productivity in seagrass beds. Geomicrobiol J 4:21-51 Rooney-Varga JN, Devereux R, Evans RS, Hines MA (1997) Seasonal changes in the relative abundance of uncultivated sulfate-reducing bacteria in a salt marsh sediment and in the rhizosphere of Spartina alterniflora. Appl Environ Microbiol 63:3895-3901

Schaub BEM, van Gemerden H (1996) Sulfur bacteria in sediments of two coastal ecosystems: the Bassin d'Arcachon and the Etang de Prévost, France. Hydrobiologia 329: $199-210$

Smith GW, Hayasaka SS (1982) Nitrogenase activity associated with Zostera marina from a North Carolina estuary. Can J Microbiol 28:448-451

Smith GW, Hayasaka SS (1986) Tetrazolium-linked dehydrogenase as an indicator of microbial root association with seagrasses. Bot Mar 29:299-303

Sand-Jensen K, Prahl C, Stokholm H (1982) Oxygen release from roots of submerged aquatic macrophytes. Oikos 38 : $349-354$

Welsh DT, Bourquès S, de Wit R, Auby I (1997) Effect of plant photosynthesis, carbon sources and ammonium availability on nitrogen fixation rates in the rhizosphere of Zostera noltii. Aquat Microb Ecol 12:285-290

Submitted: February 18, 1998; Accepted: April 14, 1998

Proofs received from author(s): July 8,1998 